Regoeczi, E. (1970). In Plasma Protein Metabolism: Regulation of Synthesis, Distribution and Degradation, ed. M. A. Rothschild and T. A. Waldman, p. 459. New York, Academic Press.

Regoeczi, E. (1971). British fournal of Haematology, 20, 649.

Reid, H. A., and Nkruma, F. K. (1972). Lancet, 1, 218.
Sheagren, J. N., Tobie, J. E., Fox, L. M., and Wolff, S. M. (1970). Fournal of Laboratory and Clinical Medicine, 75, 481.

Shulman, N. R., Neva, F. A., Sheagren, J. N., and Canfield, C. J. (1970).

Annals of Internal Medicine, 73,295.

Tobie, J. E., Wolff, S. M., and Jeffrey, G. M. (1966). Lancet, 2, 300.

\title{
Simple Method for Detection of Infection of Peritoneum during Dialysis
}

\author{
E. N. WARDLE
}

British Medical fournal, 1973, 2, 518-520

\author{
Summary \\ The lysozyme (muramidase) content of peritoneal fluid \\ samples has been found to be an early indicator of the \\ onset of infection in the course of peritoneal dialysis. A \\ level of $10.0 \mu \mathrm{g} / \mathrm{ml}$ indicates peritoneal infection and one \\ of $7.5 \mu \mathrm{g} / \mathrm{ml}$ is highly suspicious.
}

\section{Introduction}

Early detection of peritoneal infection in the course of dialysis is clearly important. It is well recognized, however, that a positive culture from peritoneal fluid effluent does not invariably indicate significant infection of the peritoneum because contamination of the outflow fluid is common (Frank et al., 1948; Odel et al., 1948). Such positive cultures do in any case take one or two days before reports are obtained. The presence of polymorphs is taken by some as an index of infection but there is also no doubt that chemical irritation of the peritoneum with glucose enhances the diapedesis of leucocytes (Boen, 1961). Others rely on naked eye estimation of the turbidity of the fluid due to precipitation of increased protein in cold fluid but in the course of a dialysis protein loss into the peritoneum increases, and the amount of protein lost is greater in patients with glomerulonephritis than pyelonephritis (Bonomini et al., 1967).

This report concerns the simple expedient of estimating the lysozyme (muramidase) content of coincident serum and peritoneal fluid samples in order to gauge the onset of peritoneal infection.

\section{Methods}

A 5.0-ml sample of clotted blood was taken morning and evening during the course of fthree-day peritoneal dialysis (P.D.) on 50 patients, and also peritoneal effluent fluid every sixth cycle. Samples were kept at $4^{\circ} \mathrm{C}$ before estimation of the lysozyme content by the technique of Harrison et al. (1968) using Micrococcus lysodeikticus (Sigma Ltd.) as substrate and lysozyme (Sigma, grade 1) at standard dilutions of $10,5,4,3,2,1$, and $0 \mu \mathrm{g} / \mathrm{ml}$. Serum and P.D. fluid lysozyme levels were read from the standard curve. Blank readings were made to correct for turbidity of both serum and P.D. fluid. Peritoneal dialysis itself was performed by standard technique using two-litre cycles of acetate fluid containing 200 units heparin added to the first cycle only. Record was made of the turbidity of peritoneal fluid

Renal Unit, Royal Victoria Infirmary, Newcastle upon Tyne NE1 4LP E. N. WARDLE, M.B., M.R.C.P., Senior Registrar in Medicine samples, of any admixture with blood, of the subsequent bacterial culture results, and of the clinical course of the patient and whether antibiotics were added to the dialysis fluid. A simple clinical score was made by which one point was scored for clinical evidence of peritoneal infection, one for a positive bacterial culture, and another for turbid dialysate fluid.

Finally, the inhibitory capacity of extra heparin on the lysozyme assay was estimated by adding known amounts of heparin to peritoneal fluid of known lysozyme content.

\section{Results}

Serum lysozyme levels varied widely between patients with a mean level of $7.6 \mu \mathrm{g} / \mathrm{ml}$ (S.D. 5.3, range 1.0-14.7). However, the mean lysozyme content of the peritoneal fluid samples was $4.2 \mu \mathrm{g} / \mathrm{ml}$ (S.D. 1.7). This should be compared with the mean peritoneal level of $2.8 \mu \mathrm{g} / \mathrm{ml}($ S.D. 1.4) for six patients who were studied during their first peritoneal dialysis and with a mean level of $8.8 \mu \mathrm{g} / \mathrm{ml}$ (S.D. 3.3) for patients with infection of the peritoneum. Patients developing infection during the course of dialysis invariably showed a rise of peritoneal fluid lysozyme to more than $7.5 \mu \mathrm{g} / \mathrm{ml}$ and usually to above 10.0 . Generally the mean P.D. fluid/serum lysozyme ratio was $0.47 \pm 0.2$, hence an occasional patient will be seen in whom a high serum level might determine a high fluid level. The ratio rose during the course of a three-day dialysis by an average of $40 \%$, reflecting the fact that there was some rise of P.D. fluid lysozyme over the course of three days. Often during infection the P.D. fluid lysozyme content exceeded the serum level.

Listed in the table are the results of the 16 patients out of 50 who had a positive clinical score. A score of unity was usually made because of turbid peritoneal fluid but, in retrospect, only in one case was the P.D. fluid lysozyme high enough to indicate that there was infection. One case was given a unity score because of the subsequent finding of bacteria in peritoneal fluid culture, but this was clearly a false positive finding. Patients with a score of two or three units certainly had infection and, as already noted, such patients usually had lysozyme levels of $10 \mu \mathrm{g} / \mathrm{ml}$. Failure to obtain a positive culture was most certainly due in some cases to the accepted unit policy of treatment with intraperitoneal antibiotics at the first suspicion of infection.

To illustrate the uses of the assay four examples are shown in the figures. A rapid rise of P.D. fluid lysozyme indicative of peritoneal infection and an equally rapid resolution with antibiotic treatment is shown in fig. 1. A patient's graph whose P.D. fluid lysozyme was $9-10 \mu \mathrm{g} / \mathrm{ml}$ but in whom there was only slow response to therapy is shown in fig. 2. Fig. 3 shows the effect on lysozyme levels of infected peritoneal fluid, accompanied by a good response to therapy. The course of a patient with haemorrhagic pancreatitis who showed high but fluctuant levels of P.D. fluid lysozyme together with high serum levels is illustrated in fig. 4. Clearly, if peritoneal dialysis is used for treatment of pancreatitis a monitor of lysozyme levels can indicate progress. 
Results for 16/50 Patients with a Positive Score for Peritoneal Infection

\begin{tabular}{|c|c|c|c|c|c|}
\hline Culture & Turbidity & Clinical & Score & \multicolumn{2}{|c|}{$\begin{array}{c}\text { Peritoneal Dialysis } \\
\text { Fluid Lysozyme } \\
\text { ( } \mu \mathrm{g} / \mathrm{ml}) \\
\text { (Normal value } 4 \cdot 2 \pm 1 \cdot 7)\end{array}$} \\
\hline $\begin{array}{l}\overline{ \pm} \\
\bar{z} \\
\overline{-}\end{array}$ & $\begin{array}{l}+ \\
+ \\
+ \\
+ \\
+\end{array}$ & $\begin{array}{c}\bar{z} \\
\bar{z} \\
\overline{-} \\
\text { uncertain }\end{array}$ & $\begin{array}{l}1.0 \\
1.0 \\
1.0 \\
1.0 \\
1.0 \\
1.0\end{array}$ & $\left.\begin{array}{r}4.5 \\
3.6 \\
5.8 \\
5.8 \\
10.8 \\
6.8\end{array}\right\}$ & Mean 6.2 $\pm 2 \cdot 3$ \\
\hline $\begin{array}{l}\bar{z} \\
\bar{z} \\
\bar{z}\end{array}$ & $\begin{array}{l}+ \\
+ \\
+ \\
+ \\
+ \\
+\end{array}$ & $\begin{array}{c}+ \\
\text { uncertain } \\
+ \\
+ \\
+ \\
+ \\
+\end{array}$ & $\begin{array}{l}2 \cdot 0 \\
2 \cdot 0 \\
2 \cdot 0 \\
2 \cdot 0 \\
2 \cdot 0 \\
2 \cdot 0 \\
2 \cdot 0\end{array}$ & $\left.\begin{array}{r}10.5 \\
12.5 \\
8.2 \\
11.0 \\
8.6 \\
7.8 \\
12.0\end{array}\right\}$ & Mean $10.0 \pm 2.2$ \\
\hline $\begin{array}{l}+ \\
+\end{array}$ & $\begin{array}{l}+ \\
+ \\
+\end{array}$ & $\begin{array}{l}+ \\
+ \\
+\end{array}$ & $\begin{array}{l}3 \cdot 0 \\
3 \cdot 0 \\
3 \cdot 0\end{array}$ & $\left.\begin{array}{r}7 \cdot 5 \\
15 \cdot 0 \\
14 \cdot 0\end{array}\right\}$ & Mean $12 \cdot 1 \pm 3 \cdot 6$ \\
\hline 0 & 0 & + & Pancreatitis & $12 \cdot 0$ & \\
\hline
\end{tabular}

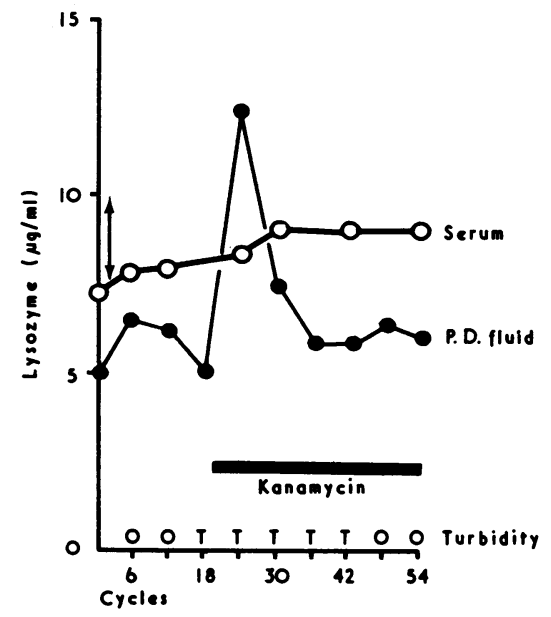

FIG. 1-Rise of peritoneal dialysis (P.D.) fluid lysozyme in peritoneal infection, and rapid response to therapy.

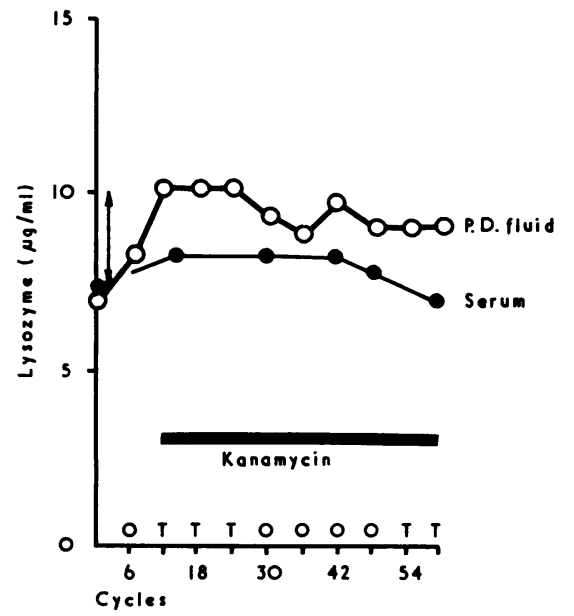

FIG. 2-Rise of P.D. fluid lysozyme, but slow response to therapy.

One point to be clarified was the finding that even a little heparin would inhibit the lysozyme assay (fig. 5). Nevertheless, since the usual dose of 400 units of heparin would be distributed in 2 litres of fluid, then this dosage could not normally invalidate the findings.

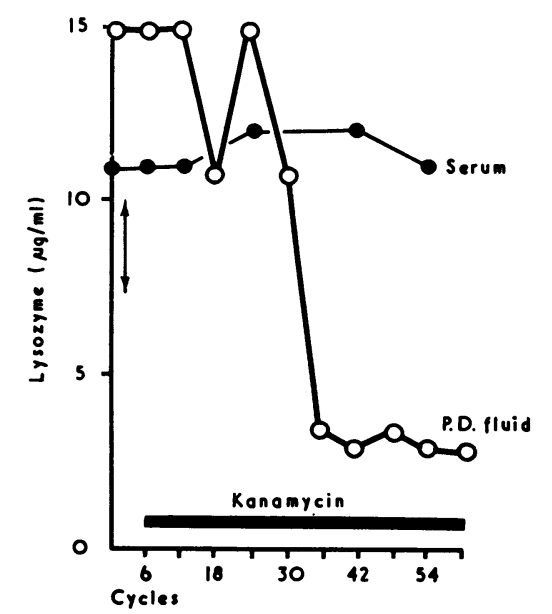

FIG. 3-Infected peritoneal fluid and good response to therapy.

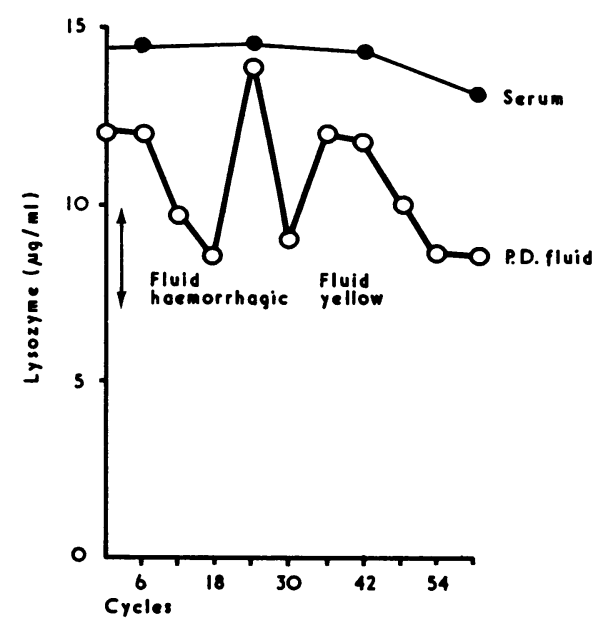

FIG. 4-Course of patient with haemorrhagic pancreatitis.

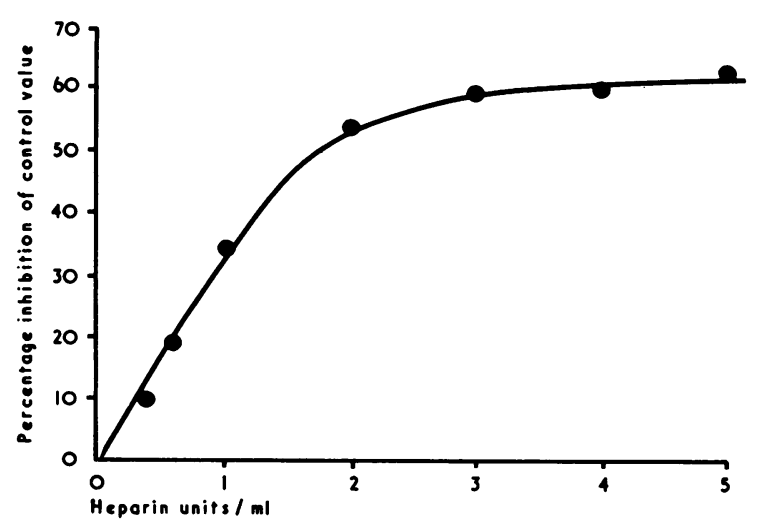

FIG. 5-Inhibition of lysozyme by heparin.

\section{Discussion}

The lysozyme test is remarkably simple to perform once the procedure has been standardized, and results can be obtained within 30 minutes. A P.D. lysozyme content of $10.0 \mu \mathrm{g} / \mathrm{ml}$ is a certain indication of peritoneal infection. A fluid content of $7.5 \mu \mathrm{g} / \mathrm{ml}$ is suspicious but must be judged in relation to the 
serum level and the previous peritoneal findings. That lysozyme levels may in fact be raised in renal failure patients is known (Prockop and Davidson, 1964), because in uraemic patients there is diminished catabolism of lysozyme by the kidney (Hansen et al., 1972). The obvious limitation is that large doses of heparin might inhibit the assay. The kinetics of such inhibition have been described by Kerby and Eadie (1953). As has been shown, however, the amount of heparin normally used in our dialysis scheme will not affect the results.

Lysozyme, an enzyme of M.W. 15,000, is normally present in tears, external secretions, and white cells (Osserman and Lawlor, 1966). It is absent from lymphocytes (Barnes, 1940) but is present in monocytes and macrophages (Myrvik et al., 1961). That it is also derived from granulocytes seems likely since the highest serum levels are found in monocytic and myelomonocytic leukaemia, and there is some elevation in all myelogenous leukaemia and during the course of bacterial infections (Crowder and White, 1968). Probably the lysozyme present in normal peritoneal fluid is partly derived from the serum and partly from white cells resident around the peritoneum. Hence in the presence of peritoneal infection a rise is to be expected and, with increasing permeability of the peritoneal membrane, levels greater than those of serum might be expected. Lysozyme is released from white cells by endotoxin or in inflammatory reactions (Tew et al., 1971).

Turbidity of cooled peritoneal fluid due to a high protein content seems to occur during the course of dialysis without necessarily implying infection, although it must indicate serous exudation. That this is so is indicated by the patients in the table listed as having a score of unity. This suspicion is further reinforced by the observation that for some reason turbidity can be intermittent. Also on one occasion a positive culture was obtained as a result of contamination, for there was no other indication of infection. Hence an additional way of diagnosing peritoneal infection is needed. Chronic renal failure patients are susceptible to infection and Stewart et al. (1966) recorded peritonitis in $6 \%$ of all treatments, and a positive blood culture appeared in another $12 \%$ during the course of four-day dialyses.

This study indicates that the use of lysozyme assay will not only aid patient management but also be of value for studies of peritoneal infection.

I am grateful to Dr. P. R. Uldall under whose care these patients were at the Newcastle General Hospital, to the nurses of the dialysis unit for their co-operation, and also to Professor D. N. S. Kerr for his support. The project was supported by the Scientific Research Committee of the Royal Victoria Infirmary, Newcastle upon Tyne.

\section{References}

Barnes, J. M. (1940). British fournal of Experimental Pathology, 21, 264. Boen, S. T. (1961). Medicine, 40, 243.

Bonomini, V., Zucchelli, P., and Mioli, V. (1967). Proceedings of the European Dialysis and Transplant Association, 4, 146.

Crowder, J. G., and White, A. C. (1968). American Fournal of Medical Sciences, 255, 327. Frank, H. A., Seligman, A. M., and Fine, J. (1948). Annals of Surgery, 128,

Harrison, J. F., Lunt, G. S., Scott, P., and Blainey, J. D. (1968). Lancet, 1, 371.

Hansen, N. E., Karle, H., Anderson, V., and Olgaard, K. (1972). Fournal of Clinical Investigation, 51, 1146.

Kerby, G. B., and Eadie, G. S. (1953). Proceedings of the Royal Society for Experimental Biology and Medicine, 83, 112.

Myrvik, Q. N., Leake, E. S., and Farris, B. (1961). fournal of Immunology,

Odel, H. M., Ferris, D. O., and Power, M. H. (1948). Medical Clinics of North America, 32, 989.

Osserman, E. F., and Lawlor, D. P. (1966). Fournal of Experimental Medicine, $124,921$.

Prockop, D. J., and Davidson, W. D. (1964). New England fournal of Medicine, 270, 269.

Stewart, J. H., Tuckwell, L. A., Sinnett, S. F., Edwards, K. D. G., and Whyte, H. M. (1966). Quarterly fournal of Medicine, 35, 407.

Tew, J. G., Scott, R. L., and Donaldson, D. M. (1971). Proceedings of the Society for Experimental Biology and Medicine, 136, 473.

Wing, W. T., and Uldall, R. (1970). Lancet, 1, 297.

\section{PRELIMINARY COMMUNICATIONS}

\section{Effect of Copper-containing Intrauterine Contraceptive Devices on Human Cells in Culture}

\section{R. W. JONES, N. M. GREGSON, MAX ELSTEIN}

British Medical fournal, 1973, 2, 520-523

\section{Summary}

Intrauterine devices containing copper were introduced into cultures of adult and fetal cells. The Dalkon shield had no apparent effect on cell growth. The Gravigard device caused inhibition of growth and an increase in

\footnotetext{
Department of Human Reproduction and Obstetrics, Southampton University Hospital, Southampton

R. W. JONES, F.R.C.S., M.R.C.O.G., Lecturer

MAX ELSTEIN, M.D., M.R.C.O.G., Senior Lecturer

Cytogenetics Unit, Department of Pathology, Salisbury General Hospital, Salisbury

N. M. GREGSON, PH.D., Cytogeneticist
}

copper concentration in the supranatant medium. When the latter device was transferred through a series of subcultures the rate of release of copper decreased and growth was no longer inhibited.

\section{Introduction}

The addition of copper wire to the surface of an inert intrauterine device (I.U.D.) has been the most significant advance in recent years (Zipper et al., 1969; Newton et al., 1972). Copper and its salts have also been introduced into the plastic matrix of at least one new device (Davis, 1971). The evidence at present suggests that the site of action of the copper is confined to the uterus itself (Zipper et al., 1969; Chang and Tatum, 1970) though this may not be the only mode of action (Elstein and Ferrer, 1970). Nevertheless, concern has been expressed regarding the use of pharmacologically active and potentially toxic materials in I.U.D.s (Wolfers, 1972). The possibility of inducing teratogenic effects in man cannot necessarily be excluded by experiment in animals whose reproductive physiology often differs greatly from that of man.

It was therefore decided to examine the effects of two new, though quite different, copper-containing I.U.D.s on human and fetal tissue culture systems. In one device (Dalkon shield, A. H. Robins) the copper is largely within the plastic matrix and in the other (Gravigard, G. D. Searle) a copper wire is wound on to the inert plastic stem of the device. 